\title{
In Vitro Antibacterial, Antifungal and Other Medical Properties of Endangered Medicinal Plant Seeds
}

\author{
Mohammed A. Almalki \\ Biological Sciences Department, College of Science, King Faisal University, Hofuf, KSA \\ Email:malmalki@kfu.edu.sa, almalkikfu@gmail.com
}

How to cite this paper: Almalki, M.A. (2017) In Vitro Antibacterial, Antifungal and Other Medical Properties of Endangered Medicinal Plant Seeds. Pharmacology \& Pharmacy, 8, 189-204. https://doi.org/10.4236/pp.2017.85013

Received: April 25, 2017

Accepted: May 24, 2017

Published: May 27, 2017

Copyright $\odot 2017$ by author and Scientific Research Publishing Inc. This work is licensed under the Creative Commons Attribution International License (CC BY 4.0).

http://creativecommons.org/licenses/by/4.0/ (c) (i) Open Access

\begin{abstract}
The risk created by infectious microorganisms to humans attracted the development of common medicine. To find an alternative source, medicinal plants with diverse metabolites play an important role in curing the diseases and human disorders caused by microbial pathogens. Medicinal plants namely, Citrullus colocynthis, Hyoscyamus muticus, Ocimum basilicum, Amaranthus lividus, Salvia aegyptiaca and Ruta chalepensis are commonly used as a traditional medicine in Gulf countries. The present study aimed to investigate the antibacterial, antifungal and antioxidant potential of the organic crude extracts obtained from the seeds. Besides, the possible antimicrobial mechanisms of the extracts were evaluated by determining the enzyme activities. The antibacterial and antifungal activities of the crude extracts were evaluated by the broth micro dilution method and the effect of the extracts on the pathogens were determined by quantifying the alkaline phosphatase (ALP), lactate dehydrogenase (LDH) enzymes and intracellular protein leakage. Besides, the antioxidant properties were determined using hydroxyl radical scavenging assay, DPPH radical scavenging assay, reducing power assay and superoxide radical scavenging assay. Results indicated that the extracts of $C$. colocynthis showed promising activity against all the tested pathogens, especially the MIC values were ranged from 100 to $150 \mu \mathrm{g} / \mathrm{ml}$ for Gram positive bacteria and 100 to $250 \mu \mathrm{g} / \mathrm{ml}$ for Gram negative bacteria respectively. The MIC values of $H$. muticus, $O$. basilicum and $R$. chalepensis against the fungal pathogens were ranged from 100 to $500 \mu \mathrm{g} / \mathrm{mL}$ respectively. The ALP activity was higher in extract treated Klebsiella pneumoniae compared with control, whereas the LDH and protein concentrations for Escherichia coli and Staphylococcus aureus were comparatively higher. Furthermore, all the studied seed extract showed good antioxidant activities. In conclusion, the studied plant seed extracts documented good antimicrobial and antioxidant activities. Therefore, the medicinal plants would be the excellent source for natural antioxidant and
\end{abstract}


antibacterial agents for medical and applications.

\section{Keywords}

Medicinal Plants, Antimicrobial Activities, Antifungal Activities, Mechanism of Antimicrobial Action, Antioxidant Properties

\section{Introduction}

Bacteria, fungi, viruses and parasites create infectious disease to human. Among the bacterial pathogens, different species including Enterococci, Salmonella, Staphylococcus, Bacillus, and Pseudomonas are the major causative agents for the symptom of fever, diarrhea, cough and other human infections [1]. Various infections and disorders caused by these pathogenic strains were cured by the innovative discovery of modern medicine and antibiotics. However, the frequent usage of the common antibiotics and therapeutic compounds for the prevention of disease causing pathogens triggered to the emergence of microbial resistance to the commonly used antibiotics. Also, the production of novel antimicrobial compounds by chemical and pharmaceutical industry has increased tremendous improvement, however, the spreading of the diseases were not comparatively reduced, whereas; creates other side effects such as immune suppression, allergic reactions and hypersensitivity reactions respectively [2]. Therefore, there is an urgent need for the invention of novel molecules with fewer side effects. At present, more than $60 \%$ of the world's population is using plant based medicine in the healthcare units [3]. In this regards, novel lead molecules isolated from active beneficial bacteria and traditional rare medicinal plants would be the alternative route for the development good active formulations with side effects. Among the isolated compounds, the novel molecules recovered from plants are shown to produce lesser side effects than the commonly used antibiotics [4]. During the twentieth century, many researchers were interested to identify the useful medicinal plants to unlock the secrets of ancient herbal remedies with various ailments. Indeed, antibacterial, antifungal, antioxidant, antibiofilm, anticancer, antidiabetic, antihpertension, and other cardiovascular protective properties of medicinal plants are reported from different parts of the world [5]. The phytochemicals such as phenolic compounds, flavanoids, anthocyanins, alkaloids, terpernoids, saponins and quinine molecules obtained from traditional medicinal plants are mainly responsible for their potential activity [6] [7] [8] [9]. Due to the presence of wide range of metabolites, medicinal plants from Gulf countries especially kingdom of Saudi Arabia were investigated for various activities [10] [11] [12]. Recently, Al-Juraifani (2011) investigated the antibacterial and antifungal potential of Thymus vulgaris, Salvia officinalis, Boswelia carterii and Boswelia carterii against Bacillus cereus, Staphylococcus aureus, Streptococcus sp., Micrococcus luteus Vibrio tubiashii, Cellulosimicrobium cellulans, Fusarium oxysporum and Aspergillus flavus respectively [13]. Like other coun- 
try Saudi Arabia is also rich in traditional medicinal plants with various biological activities.

Citrullus colocynthis $\mathrm{L}$ distributed in the desert area of gulf region belong to cucurbitaceae family contains alkaloids such as colocythin and colocynthidin, cucurbitacin, saponin and glycosides were traditionally used in the treatment of jaundice and constipation [14]. Species of Hyoscyamus belong to Solanaceae family, known for the presence of many phytochemicals such as hyoscine, apohyoscine, belladonines apoatropine, hyoscyamine, skimmianine, tropine caturamine, hyoscypicrin, apoatropine, cuscohygrine, phytin, tropine, hyoscine aphoyoscine choline, alpha and beeta belladonine and hyoscine respectively with various biological activities [15]. Ocimum basilicum (Lamiaceae) is another widely studied medicinal plant commonly observed in the warm temperate region is known for its applications towards the treatment of diarrhea, pneumonia, fever respiratory tract infections, ophthalmic, headache, cough, skin disease, and conjunctivitis respectively [16]. Amaranthus lividus is also distributed in the warm places and is used in the treatment of various disorders [17]. Salvia aegyptiaca is known for the presence of abietane, diterpenoids, triterpenoids and sesquiterpenoids with antimicrobial and anti-leishmania activities [18]. Ruta chalepensis is widely used in the treatment of urinary tract infections and the phytochemicals recovered from this plant exhibited comparatively better antimicrobial activity against the clinical pathogens [19]. With these information's, the present study aimed to investigated the antimicrobial and antioxidant properties of the seeds of $C$. colocynthis, $H$. muticus, $O$. basilicum, A. lividus, $S$. aegyptiaca and $R$. chalepensis. In addition the possible antimicrobial mechanism of the extract of the seeds also determined.

\section{Materials and Methods}

\subsection{Collection of Plant Seed Materials}

Seeds of six medicinal plants namely $C$. colocynthis, $H$. muticus, $O$. basilicum, $A$. lividus, $S$. aegyptiaca and $R$. chalepensis were collected from the desert region of gulf countries.

\subsection{Solvent Extraction of Seeds}

Seeds of the medicinal plants were collected and shade dried for three days before solvent extraction. For solvent extraction, the seeds were finely powdered using the blender and the powder was mixed with ethyl acetate. Further, the mixture was thoroughly vortexed and rapped with air-tight cotton plug and tightly covered with aluminum foil. After that the mixtures containing flask was kept in the orbital shaker and mixed in the gradual speed of $100 \mathrm{rpm}$ for three days. Finally, the mixtures was filtered using the whatman No-1 filter paper and the collected supernatant was further centrifuged at $12000 \mathrm{rpm}$ for $15 \mathrm{~min}$ for complete removal of the debris. The debris free supernatant was concentrated using vacuum evaporator at $40^{\circ} \mathrm{C}$ which was maintained by supplying chilled water under reduced pressure. The collected solvent phase was discarded and the 
concentrate containing the photochemical were transferred into the air-tight brown bottle and safely stored in the cold cabinet for further experiments.

\subsection{In-Vitro Antimicrobial Activity}

\subsubsection{Pathogenic Microbial Strains}

A total of seven Gram positive and Gram negative bacterial strains namely, Bacillus subtilis (MTCC 441), Enterococcus faecalis (ATCC 29212), Staphylococcus aureus (ATCC 25923), Staphylococcus epidermidis (MTCC 3615), Escherichia coli (ATCC 25922), Klebsiella pneumoniae (ATCC 15380), Pseudomonas aeroginosa (ATCC 27853) and six filamentous fungi namely, Aspergillus niger (KACC 40280), Botrytis cinerea (KACC 40573), Candida albicans (KACC 30003), Curvalaria lunata (KACC 40392), Fusarium oxysporum (KACC 40051) and Gibberella moniliformis (KACC 44022) were evaluated for the antimicrobial activity.

\subsubsection{Antimicrobial Activity}

Antibacterial activity of the extract was determined by disc diffusion method [6]. Briefly, the bacterial strains were freshly prepared and sub-cultured before performing the experiment. Fifty micro liter of active cell suspension were evenly spread on the nutrient agar plates in aseptic condition. After that the sterile disc impregnated with the extracts were placed on the top of the plates and incubate at $37^{\circ} \mathrm{C}$ for $17 \mathrm{~h}$. The antimicrobial activity was determined by measuring the zone of inhibition around the discs. This experiment was performed in triplicates. Whereas for determination of antifungal activity, the fungal spore suspension were mixed with sterile semi-solid potato dextrose agar together with the varying concentrations of the extract. Attention must take care that the fungal spore and the extract should be mixed when the temperature is around $50^{\circ} \mathrm{C}$. Control plate was maintained without addition of the extract. After incubation at $30^{\circ} \mathrm{C}$ for two days, antifungal activity was determined by comparing the difference in the fungal biomass growth. This experiment was performed in triplicates for further confirmation.

\subsubsection{Minimum Inhibitory Concentration (MIC)}

Standard reported method was followed for the determination of minimum inhibitory concentration in 96 well plate [6].

\subsection{Determination of Mechanism of the Antimicrobial Activity of the Extract}

\subsubsection{Alkaline Phosphatase (ALP) Quantification}

The content alkaline phosphatase (ALP) was quantified by following the modified method of Arokiyaraj et al. 2014 [20].

\subsubsection{Lactate Dehydrogenase (LDH) Quantification}

Lactate dehydrogenase (LDH) is present in the cytoplasm of the bacteria. LDH level was analyzed to determine the damage caused by the extract to the pathogenic bacteria. The LDH level was quantified by following the method of Arokiyaraj et al. (2014) [20]. 


\subsubsection{Intracellular Protein Leakage}

The effect of the extract in the intracellular protein level was monitored. For evaluating the extracts influence in the intracellular protein levels, the freshly grown bacteria were cultivated by supplementing the extract. After that the cells were cultivated under micro-aerobic condition in the shaking incubator for $24 \mathrm{~h}$. After incubation the supernatant was collected and level of protein was measured by following the method of Bradford (1976) [21].

\subsection{In-Vitro Antioxidant Activities}

\subsubsection{Hydroxyl Radical Scavenging Activity}

In vitro hydroxyl scavenging activity of the seed extract was determined by following the method of Sunil et al. (2014) [22].

Scavenging activity $(\%)=[1-($ absorbance of sample-absorbance of blank $) /$ absorbance of control] $\times 100$

\subsubsection{DPPH Radical Scavenging Assay}

The DPPH scavenging activities of the compounds were determined by following the method of Hanato et al. (1988) [23].

Scavenging activity $(\%)=[1-($ absorbance of sample-absorbance of blank $) /$ absorbance of control] $\times 100$

\subsubsection{Reducing Power}

Reducing power of the metabolites was determined by following the method of Oyaizu, (1986) [24]. BHT at various concentrations was used as standard. Increased absorbance of the reaction mixture indicates increase in reducing power.

\subsubsection{Superoxide Radical Scavenging Assay}

As described by Sunil et al. [22] NBT (tetrazolium reagent) method was followed for the superoxide radical scavenging assay.

Scavenging activity $(\%)=[1-($ absorbance of sample-absorbance of blank $) /$ absorbance of control] $\times 100$

\section{Results}

\subsection{Antibacterial Activity of the Medicinal Plant Seeds}

The antibacterial activity of the selected six medicinal plant seeds ethyl acetate extracts are showed in Table 1. The MIC results revealed variable degrees of activity against Gram positive and Gram negative bacterial pathogens, with MICs values ranging from 100 to $250 \mu \mathrm{g} / \mathrm{ml}$. Among the plants, the extracts of $C$. colocynthis showed promising activity against all the tested pathogens, especially the MIC values were ranged from 100 to $150 \mu \mathrm{g} / \mathrm{ml}$ for Gram positive bacteria, and 100 to $250 \mu \mathrm{g} / \mathrm{ml}$ for Gram negative bacteria respectively. The MIC values of C. colocynthis towards B. subtilis, S. epidermidis, E. faecalis and P. aeroginosa were $100 \mu \mathrm{g} / \mathrm{ml}, S$. aureus and E. coli were $150 \mu \mathrm{g} / \mathrm{ml}$ and towards $K$. pneumoniae $200 \mu \mathrm{g} / \mathrm{ml}$ respectively. The antibacterial activity of $O$. basilicum and $A$. lividus comparatively showed similar profile towards Gram Positive bacteria. The 
Table 1. Minimum inhibitory concentration of the extracts against Gram positive and Gram negative bacteria.

\begin{tabular}{|c|c|c|c|c|c|c|c|}
\hline \multirow{2}{*}{ Microorganism } & \multicolumn{7}{|c|}{$\begin{array}{l}\text { Minimum Inhibitory Concentration (MIC) } \\
\left(\mu \mathrm{g} \cdot \mathrm{mL}^{-1}\right)\end{array}$} \\
\hline & 1 & 2 & 3 & 4 & 5 & 6 & $S$ \\
\hline \multicolumn{8}{|l|}{ Gram positive } \\
\hline Bacillus subtilis (MTCC 441) & 100 & $>500$ & 250 & 150 & $>250$ & 250 & 2.5 \\
\hline Staphylococcus aureus (ATCC 25923) & 150 & $>250$ & 250 & 100 & 250 & NA & 37.5 \\
\hline Staphylococcus epidermidis (MTCC 3615) & 100 & 250 & 150 & 150 & 100 & NA & 10 \\
\hline Enterococcus faecalis (ATCC 29212) & 100 & 150 & 100 & 250 & 150 & 100 & 25 \\
\hline \multicolumn{8}{|l|}{ Gram negative } \\
\hline Escherichia coli (ATCC 25922) & 150 & $>500$ & $>250$ & 150 & NA & 500 & 25 \\
\hline Klebsiella pneumoniae (ATCC 15380) & 250 & $>500$ & $>250$ & 100 & NA & $>500$ & 25 \\
\hline Pseudomonas aeroginosa (ATCC 27853) & 100 & 500 & $>250$ & 100 & 250 & $>500$ & 50 \\
\hline
\end{tabular}

1, Citrullus colocynthis, 2, Hyoscyamus muticus, 3, Ocimum basilicum; 4, Amaranthus lividus, 5, Salvia aegyptiaca; 6, Ruta chalepensis, S, standard antibiotics. MTCC: microbial type culture collection; ATCC: American type culture collection; MMC: NA: no activity.

MIC values of $O$. basilicum and A. lividus were ranged from 100 to $250 \mu \mathrm{g} / \mathrm{ml}$. However, the extracts of $H$. muticus, $S$. aegyptiaca and $R$. chalepensis exhibited moderate level of activity towards Gram positive and Gram negative bacteria. The MIC of the standard streptomycin were ranged from 2.5 to $50 \mu \mathrm{g} / \mathrm{ml} \mathrm{respec-}$ tively. The extracts of $S$. aegyptiaca and $R$. chalepensis did not expressed activity towards $S$. epidermidis, $S$. aureus, $P$. aeroginosa and $K$. pneumoniae.

\subsection{Antifungal Activity of the Medicinal Plant Seeds}

The antifungal activity of the selected six medicinal plant seeds extracts are presented in Table 2. Among the seeds, A. lividus showed significant activity against the filamentous fungi, $B$. cinerea revealed the lower MIC values (100 $\mu \mathrm{g} / \mathrm{mL}$ ) and other fungi such as A. niger, C. lunata, F. oxysporum, and G. moniliformis showed MIC at $125 \mu \mathrm{g} / \mathrm{mL}$ concentrations. The extracts of $C$. colocynthis, $H$. muticus, $O$. basilicum and $R$. chalepensis exhibited the MIC values ranged from 100 to $500 \mu \mathrm{g} / \mathrm{mL}$ respectively. Among the seeds, S. aegyptiaca showed the moderate activity against all the tested fungal pathogens. The extracts of $S$. aegyptiaca did not showed activity towards A. niger, B. cinerea, C. albicans and $C$. lunata, whereas the MIC values of $F$. oxysporum and $G$. moniliformis were above $500 \mu \mathrm{g} / \mathrm{mL}$ respectively. The positive control showed MIC values from $25-100 \mu \mathrm{g} / \mathrm{mL}$ for the selected fungal pathogens.

\subsection{Antimicrobial Mechanism of the Extract}

\subsubsection{Quantification of Alkaline Phosphatase (ALP)}

The quantification ALP enzyme gives further evidence that the treatment of 
Table 2. Minimum inhibitory concentration of the extracts against fungi.

\begin{tabular}{|c|c|c|c|c|c|c|c|}
\hline \multirow{2}{*}{ Microorganism } & \multicolumn{7}{|c|}{$\begin{array}{l}\text { Minimum Inhibitory Concentration (MIC) } \\
\left(\mu \mathrm{g} \cdot \mathrm{mL}^{-1}\right)\end{array}$} \\
\hline & 1 & 2 & 3 & 4 & 5 & 6 & $S$ \\
\hline Aspergillus niger (KACC 40280) & $>250$ & NA & 150 & 125 & NA & 250 & 25 \\
\hline Botrytis cinerea (KACC 40573) & 500 & 500 & 100 & 100 & NA & 250 & 50 \\
\hline Candida albicans (KACC 30003) & 125 & 500 & 100 & 100 & NA & 500 & 100 \\
\hline Curvalaria lunata (KACC 40392) & 250 & 250 & 150 & 125 & NA & 125 & 50 \\
\hline Fusarium oxysporum (KACC 40051) & 100 & $>500$ & $>150$ & 125 & $>500$ & 250 & 25 \\
\hline Gibberella moniliformis (KACC 44022) & 100 & 500 & 500 & 125 & $>500$ & 250 & 100 \\
\hline
\end{tabular}

1, Citrullus colocynthis, 2, Hyoscyamus muticus, 3, Ocimum basilicum; 4, Amaranthus lividus, 5, Salvia aegyptiaca; 6, Ruta chalepensis, S, standard antibiotics. KACC: Korean type culture collection; NA: no activity.

extracts to microbial strains strongly inhibited the bacterial cell wall and other physiological nature. Results indicated that the significant increase in the units of the ALP in the cultivation medium. ALP enzyme concentrations were dominant in the $K$. pneumoniae $(623,466,466 \mathrm{U} / \mathrm{L}$ ) treated with $C$. colocynthis, $H$. muticu and O. basilicum extract, whereas the content of the enzymes were higher in S. typhi (383 and $606 \mathrm{U} / \mathrm{L}$ ) for A. lividus and $S$. aegyptiaca respectively (Figure 1(a)). ALP was noted higher in P. aeruginosa in the case of $R$. chalepensis treatment. The increase in the concentration of the ALP enzyme proved that the plant extracts created the unfavorable environment to the bacteria which resulted in the release of the enzymes.

\subsubsection{Quantification of Lactate Dehydrogenase (LDH)}

The levels of LDH in the extract treated samples were showed in Figure 1(b). All the seeds extract exhibited higher level of enzyme in the culture broth indicated that the extracts directly attach the cell wall of the bacterial and create unfavorable condition for the growth. Particularly, the LDH level of $S$. aureus treated with C. colocynthis was $64.7 \%$ higher than the control. Also, treatment with $\mathrm{H}$. $\mathrm{mu}$ ticus exhibited $61 \%$ higher LDH in $K$. pneumoniae. Similarly, the extracts of O.basilicum, A. lividus, $S$. aegyptiaca and $R$. chalepensis pronounced comparatively higher level of LDH in the spent medium.

\subsubsection{Quantification of Intracellular Protein Leakage Level}

The results revealed that the treatment of the extract with the microbial strains showed higher release of protein in the supernatant. Among the pathogenic bacteria, the protein concentration $S$. aureus was higher $(79 \%, 76 \%, 74 \%$ and $72 \%)$ than the control in $R$. chalepensis, A. lividus, S. aegyptiaca and O.basilicum treated samples, followed by $P$. aeruginosa $(70.68 \%)$ and $K$. pneumoniae $(60.15 \%)$ in $C$. colocynthis and H. muticus (Figure 1(c)). 

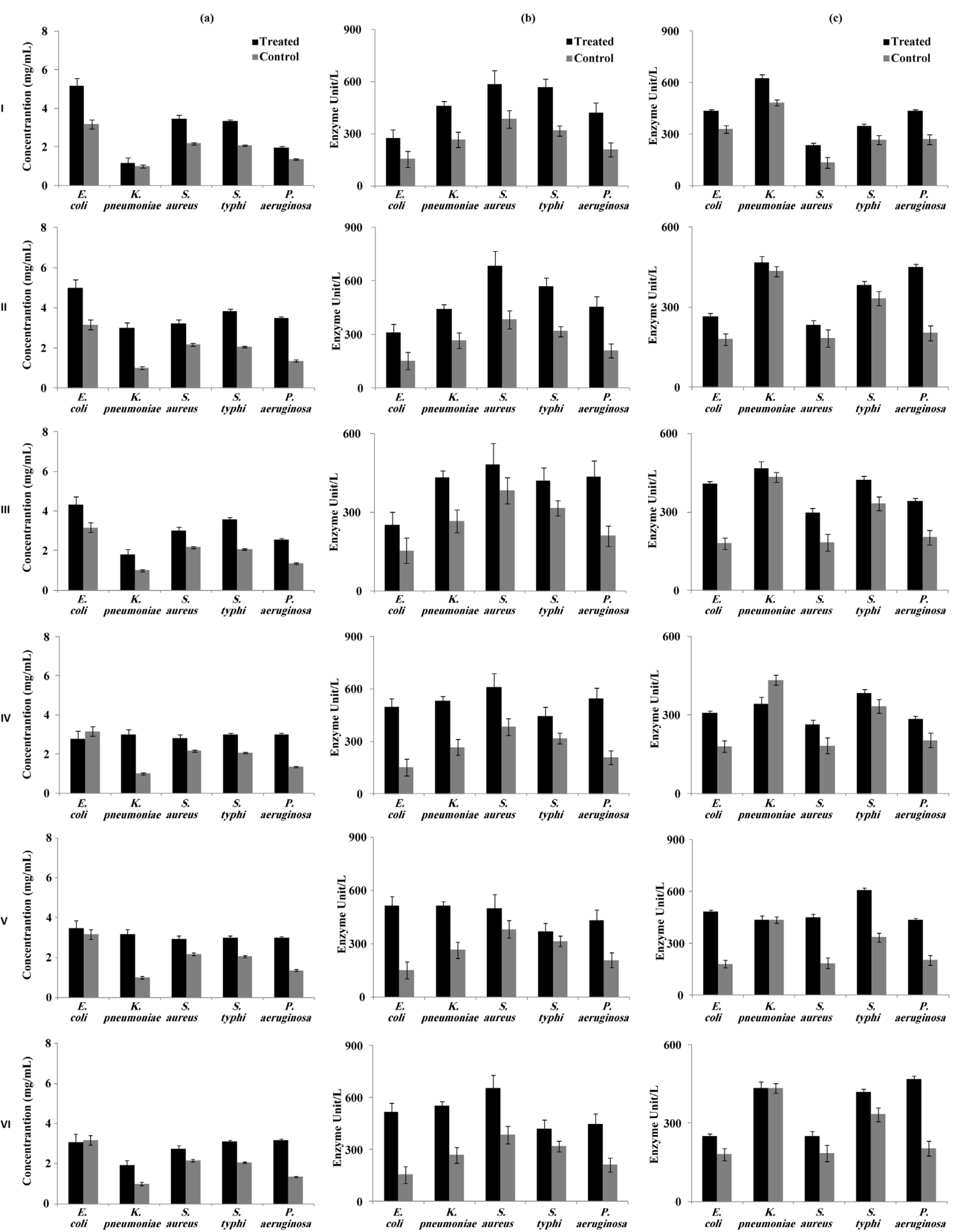

Figure 1. Antimicrobial mechanism of the extract; determined by studying the enzyme activities. I, Citrullus colocynthis, II, Hyoscyamus muticus, III, Ocimum basilicum; IV, Amaranthus lividus, V, Salvia aegyptiaca; VI, Ruta chalepensis; (a), Quantification of Alkaline phosphatase (ALP); (b), Quantification of Lactate dehydrogenase (LDH); (c), Quantification of intracellular protein leakage level. 


\subsection{Antioxidant Activity of the Medicinal Plant Seeds}

\subsubsection{Hydroxyl Radical Scavenging Activity}

The ability of the seeds extracts to scavenge the hydroxyl radical is displayed in Figure 2(a). All the seeds extracts revealed the scavenging activity in a dose dependent manner. In particular for C. colocynthis, the concentrations for $50 \%$ inhibition were found to be 163 and $125 \mu \mathrm{g} / \mathrm{mL}$ for the crude ethyl acetate extract and BHT, respectively. The $50 \%$ inhibition of other seeds extracts were noted in the figure.

\subsubsection{DPPH Radical Scavenging Assay}

The ability of the seeds extracts to scavenge DPPH free radicals are shown in Figure 2(b). All the seeds extract revealed varying scavenging effects. However, the DPPH scavenging activities were noted as the dose dependent manner. Fifty

(a)

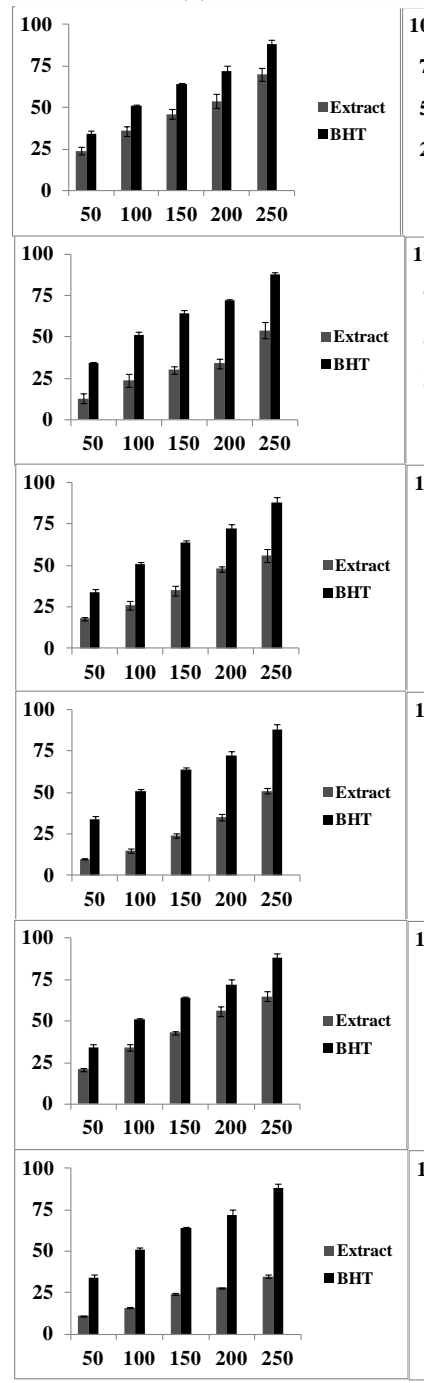

(b)

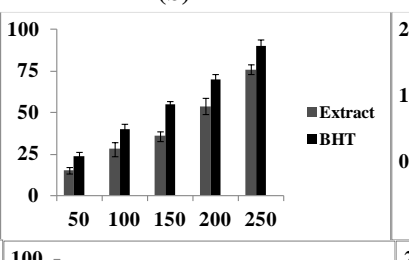

(c)<smiles>CCCCC</smiles>

(d) 
percentage scavenging ability of the extracts were were found to be 208, 242, 233, 242, 147 and $312 \mu \mathrm{g} / \mathrm{mL}$ for C. colocynthis, H. muticus, O. basilicum, A. lividus, $S$. aegyptiaca and $R$. chalepensis respectively. All the extracts revealed the highest scavenging rates at $76 \%, 51 \%, 70 \%, 57 \% 83 \%$ and $36 \%$ at $250 \mu \mathrm{g} / \mathrm{mL}$ concentration whereas standard BHT showed $90 \%$ at $2500 \mu \mathrm{g} / \mathrm{mL}$ concentration.

\subsubsection{Reducing Power}

The reducing power ability of the extracts was compared to the standard BHT (Figure 2(c)). Results indicated that all the six extracts exhibited differences in their reducing power reactions. In general, all the extracts comparatively showed good reducing power with respect to the concentration of the extract.

\subsubsection{Superoxide Radical Scavenging Assay}

Figure 2(d) displayed the superoxide radical scavenging activity of the seed extract. Comparatively, all the extracts showed the similar superoxide radical scavenging activity and the activity was directly proportional to the concentration of the crude extract. Fifty percentage of superoxide anion radical generation was scavenged at 221,277, 179, 278, 167 and $313 \mu \mathrm{g} / \mathrm{mL}$ concentration for C. colocynthis, H. muticus, $O$. basilicum, A. lividus, $S$. aegyptiaca and $R$. chalepensis respectively.

\section{Discussion}

Novel active lead molecules recovered from different medicinal plants throughout the world create the foundation for the development of new antibiotic or the therapeutic products for the treatment of infectious disease caused by pathogenic microbial strains including bacteria and fungi because of its safe use than the modern synthetic drugs with number of side effects [7]. It is estimated that $80 \%$ of the world population attracted the consumption of natural products from various traditional medicinal plants especially herbal medicinal plants contain secondary metabolites such as flavanoids, alkaloids, terpenoids, anthocyanins and saponins with anticancer, antioxidants, antihypertention, anti-inflammatories, anticoagulant, antidiabetic, and other cardiovascular diseases. Also, the novel plant derived molecules involved in the enhancement of the immune system further prolonging the life style [25]. In the recent years, many studies have been done to evaluate the antimicrobial properties of medicinal plants in many countries. Similarly, medicinal plants such as Datura stramonium, Zygophyllum coccineum, Lasiurus scindicus and Heliotropium digynum from Saudi Arabia has also explored for the antimicrobial potential against various microbial pathogens [26]. However, it is worthy for the identification of potential medicinal plants from Saudi Arabia with various antimicrobial properties [27]. Especially, plants such as $C$. colocynthis, $H$. muticus, $O$. basilicum, A. lividus, S. aegyptiaca and $R$. chalepensis have wide level of biological applications attract the researchers to investigate their antimicrobial properties. Therefore, the seeds of $C$. colocynthis, $H$. muticus, $O$. basilicum, A. lividus, $S$. aegyptiaca and $R$. chalepensis were collected from the desert region of Saudi Arabia and investigated its antimicrobial 
and antioxidant properties. Preliminary screening of the crude extract obtained from the seeds documented comparatively significant antimicrobial activities. There antimicrobial mechanism of the extracts was determined by evaluating the enzyme concentration in the spent medium. Further, the in vitro antioxidant properties also evaluated.

From the results, The MIC values of the selected plants extracts against Gram positive and Gram negative microbial pathogens were ranged from 100 to 500 $\mu \mathrm{g} / \mathrm{mL}$. The results indicated that the lowest MIC value $(100 \mu \mathrm{g} / \mathrm{ml})$ of the extracts of $A$. lividus was against $S$. aureus, $K$. pneumoniae and $P$. aeroginosa. MIC value was comparatively higher $(500 \mu \mathrm{g} / \mathrm{ml})$ against uropathogenic bacteria $E$. faecalis. The activity of the extracts against the Gram negative bacteria was interesting, especially, the extracts of $C$. colocynthis documented the lowest MIC $(100 \mu \mathrm{g} / \mathrm{mL})$ was recorded against $P$. aeruginosa and the highest MIC (250 $\mu \mathrm{g} / \mathrm{mL}$ ) was recorded against $K$. pneumoniae. E. coli showed moderate level of MIC values $(150 \mu \mathrm{g} / \mathrm{mL})$. Against all the tested microbial pathogens, we noted that the A. lividus extract produced much better antibacterial activities. These results were coincides with the report of Marzouk et al. (2010) and Padalia et al. (2014), where the extract of C. colocynthis and O. basilicum showed promising antimicrobial activity against Gram-positive ( $S$. aureus and $E$. faecalis) and Gram-negative ( $P$. aeruginosa and $E$. coli) respectively [28] [29]. The present study confirmed that the Gram positive bacteria are more susceptible to all the tested extracts as they have a susceptible cell wall layer [30]. The urinary infection causing $K$. pneumoniae, E.coli and P. aeroginosa also revealed moderate activity against all the six extracts, even though the bacteria contains thick cell wall membrane which rarely permit the molecules inside the cells [30].

The increasing rate of fungal infections such as aspergillosis and candidiasis leads to severe immune-suppression diseases [31]. In the present study all the extracts exhibited comparatively moderate activity against all the tested fungi and the MIC values ranged within $100-500 \mu \mathrm{g} / \mathrm{mL}$ respectively. The extract of C. colocynthis, documented MIC value $>250 \mu \mathrm{g} / \mathrm{mL}$ for $A$. niger, $500 \mu \mathrm{g} / \mathrm{mL}$ ( $B$. cinerea), $125 \mu \mathrm{g} / \mathrm{mL}$ (C. albicans), $250 \mu \mathrm{g} / \mathrm{mL}$ (C. lunata), $100 \mu \mathrm{g} / \mathrm{mL}$ (F. oxysporum) and $100 \mu \mathrm{g} / \mathrm{mL}$ (G. moniliformis). Similarly, Eidi et al. (2015), claimed that the crude extract of $C$. colocynthis documented the MIC of 1.56 to 12.5 $\mathrm{mg} / \mathrm{ml}$ against Aspergillus fumigates, A. niger, Candida guilliermondii and Candida kreusei respectively [32]. The inhibitory activity of the extract might be due to the presence of active compounds including glucosides and resins which are water soluble and inhibit enzymatic activity in the cytoplasmic membrane [33]. Cota et al. (2013), reported that the phytochemicals present in the medicinal plants actively diffuse through the cytoplasmic membrane and compete for the active sites of certain enzymes inside the cell thereby arresting the strains to grow [34]. In addition many studies evidenced the antifungal activity of $C$. colocynthis [35] [36] [37].

The antimicrobial mechanisms of the plant derived metabolites were elucidated by several researchers. However, the exact mechanisms of action were not 
completely reported. Researchers claimed that the active molecules attach the cell wall of the pathogenic microorganisms and create the unfavorable environment to the outer cellular membranes leading to the alteration of cellular contents and leakage of inner membrane contents [38]. Relatively, constituents of plants such as phenolics, flavonoids, quinines, tannins, coumarins, alkaloids, terpenoids, lectins and polypeptides inhibit the ATPase syntheses which directly stimulate the alteration in the physiology of the bacterial cells and leads to cell death [39] [40] [41]. The phenolic compounds derived are known for the lysis of cell membranes and cause cell death [39] [42]. Similarly, the present report claimed that the crude extracts of the six medicinal plants documented variation in the cellular components especially the contents of total protein and the units of enzymes such as ALP and LDH. Therefore, it is attributed that the combination of the phyto constituents present in the seed extracts of the medicinal plants create cell damage, causing leakage of cellular materials and resulted in the suppression of cell growth.

Molecules prevent or stop the oxidation of cellular components are known as antioxidants [43]. In general, most of the identified medicinal plants functional compounds such as alkaloids (terpenoid indole alkaloids, tropane alkaloids and purine alkaloids), terpenoids (monoterpenes, sesquiterpenes and diterpenes), carotenoids (beta-carotene), phenolics (phenolic acids, flavonoids, lignans, stilbenes and tannins) have the promising antioxidant potentials [44] [45]. Among the different functional metabolite, phenolic compounds protect the human body from various major causative agents for various life threatening diseases, including neurodegenerative and cardiovascular disease respectively [46]. Similar to the report, in the present study, the plant materials exhibited comparatively good antioxidant activity. Yoshikawa et al. (1997) and Nirmala and Ramanathan, (2011) reported that the presence of phenolic compounds in the medicinal plant materials enhance the activity of antioxidant enzymes such as glutathione peroxidase, superoxide dismutase and catalases respectively [47]. The extracts obtained from the medicinal plants could be useful for the protection of oxidative stress related diseases.

\section{Conclusion}

In conclusion, the antibacterial, antifungal and antioxidant properties of six medicinal plants seed collected from Saudi Arabia were investigated. All the extracts revealed good antibacterial activity against the Gram positive and Gram negative pathogens, especially the MIC of the extracts against the fungal pathogens were ranged from 100 to $500 \mu \mathrm{g} / \mathrm{mL}$ respectively. All the studied extracts showed promising activity against the filamentous fungal pathogens. The mechanisms of antimicrobial potential of the extracts were confirmed by evaluating the contents of ALP, LDH and extracellular protein contents. The elevated levels of the enzyme concentration in the extract treated microbial pathogens were its advantage. Additionally, all the extract showed promising antioxidant activity. Future studies would plan to isolate the novel active metabolites from the crude 
extract and investigate its application in treating infectious diseases and oxidative stress-related diseases. Also, accurate in vitro cultivation methods would be developed for the propagation of the medicinal plants for bulk cultivation.

\section{Conflict of Interest}

Declare no conflict with the manuscript.

\section{References}

[1] Bibi, Y., Nisa, S., Chaudhary, F.M. and Zia, M. (2011) Antibacterial Activity of Some Selected Medicinal Plants of Pakistan. BMC Complementary and Alternative Medicine, 11, 52. https://doi.org/10.1186/1472-6882-11-52

[2] Adwan, G. and Mhanna, M. (2008) Synergistic Effects of Plant Extracts and Antibiotics on Staphylococcus aureus Strains Isolated from Clinical Specimens. Middle-East Journal of Scientific Research, 3, 134-139.

[3] Awouafack, M.D., McGaw, L.J., Gottfried, S., Mbouangouere R., Tane, P., Spiteller, M. and Eloff, J.N. (2013) Antimicrobial Activity and Cytotoxicity of the Ethanol Extract, Fractions and Eight Compounds Isolated from Eriosema robustum (Fabaceae). BMC Complementary and Alternative Medicine, 13, 289. https://doi.org/10.1186/1472-6882-13-289

[4] Walsh, F.M. and Amyes, S.G. (2011) Microbiology and Drug Resistance Mechanisms of Fully Resistant Pathogens. Current Opinion in Microbiology, 7, 439-444.

[5] Bhalodia. N.R. and Shukla, V.J. (2011) Antibacterial and Antifungal Activities from Leaf Extracts of Cassia fistula 1: An Ethnomedicinal Plant. Journal of Advanced Pharmaceutical Technology, 2, 104-109. https://doi.org/10.4103/2231-4040.82956

[6] Rejiniemon, T.S., Arasu, M.V., Duraipandiyan V., et al. (2014) In Vitro Antimicrobial, Antibiofilm, Cytotoxic, Antifeedant and Larvicidal Properties of Novel Quinone Isolated from Aegle marmelos (Linn.) Correa. Annals of Clinical Microbiology and Antimicrobials, 13, 48. https://doi.org/10.1186/s12941-014-0048-y

[7] Antonisamy, P., Duraipandiyan, V., Ignacimuthu, S. and Kim, J.-H. (2015) Anti-Diarrhoeal Activity of Friedelin Isolated from Azima tetracantha lam. in Wistar Rats. South Indian Journal of Biological Sciences, 1, 34-37. https://doi.org/10.22205/sijbs/2015/v1/i1/100440

[8] Balamurugan, R. (2015) Smilax chinensis Linn. (Liliaceae) Root Attenuates Insulin Resistance and Ameliorate Obesity in High Diet Induced Obese Rat. South Indian Journal of Biological Sciences, 1, 47-51. https://doi.org/10.22205/sijbs/2015/v1/i1/100443

[9] Abou-zeid, A.M., Altalhi, A.D. and El-Fattah, R.I. (2008) Fungal Control of Pathogenic Fungi Isolated from Some Wild Plants in Taif Governorate, Saudi Arabia. Malaysian Journal of Microbiology, 4, 30-39.

[10] Fardos, M.B. (2009) Antifungal Activity of Some Medicinal Plants Used in Jeddah, Saudi Arabia. Mycophathology, 7, 51-57.

[11] Nehal, S.E. and Rokayah, S.A. (2009) Inhibitory Effects of Powdered Caraway and Peppermint Extracts on Pea Root Rot under Greenhouse Conditions. Saudi Journal of Plant Protection Research, 49, 93-96.

[12] Al-Juraifani, A.B. (2011) Antimicrobial Activity of Some Medicinal Plants Used in Saudi Arabia. Canadian Journal of Pure and Applied Sciences, 5, 1509-1512.

[13] Alkamel, M.L. (2005) Antimicrobial Activity of Aqueous Extract of Citrullus colocynthis L. Fruit. Tikrit Journal of Pharmaceutical Sciences, 1, 9-15. 
[14] Dulger, B., Ceyhan, M., Alitsaous, M. and Ugurlu, E. (1999) Artemisia absinthium L. (Pelin)'un Antimikrobiyal Aktivitesi. Turkish Journal of Biology, 23, 377-384.

[15] Keita, S.M., Vincent, C., Schmidt, J.P. and Arnason, J.T. (2000) Insecticidal Effects of Thuja occidentalis (Cupressaceae) Essential Oil on Callosobruchus maculatus (Coleoptera: Bruchidae). Canadian Journal of Plant Science, 81, 173-177. https://doi.org/10.4141/P00-059

[16] He, H.P., Cai, Y., Sun, M. and Corke, H. (2002) Extraction and Purification of Squalene from Amaranthus Grain. Journal of Agricultural Food Chemistry, 50, 368 372. https://doi.org/10.1021/jf010918p

[17] Mehmood, S., Riaz, N., Ahmad, Z., Afza, N. and Malik, A. (2008) Lipoxygenase Inhibitory Lignans from Salvia santolinifolia. Polish Journal of Chemistry, 82, 571 575.

[18] Rathi, M.A., Meenakshi, P. and Gopalakrishnan, V.K. (2015) Hepatoprotective Activity of Ethanolic Extract of Alysicarpus vaginalis against Nitrobenzene-Induced Hepatic Damage in Rats. South Indian Journal of Biological Sciences, 1, 60-65. https://doi.org/10.22205/sijbs/2015/v1/i2/100420

[19] Arokiyaraj, S., Choi, S.H., Lee, Y., Bharanidharan, R., Hairul-Islam, V.I., Vijayakumar, B., Oh, Y.K., Dinesh-Kumar, V., Vincent, S. and Kim, K.H. (2015) Characterization of Ambrette Seed Oil and Its Mode of Action in Bacteria. Molecules, 20, 384-395. https://doi.org/10.3390/molecules20010384

[20] Bradford, M.M. (1976) A Rapid and Sensitive Method for the Quantification of Microgram Quantities of Protein Utilizing the Principle of Protein Dye Binding. Analytical Biochemistry, 72, 248-254.

[21] Santhosh, S.K., Venugopal, A. and Radhakrishnan, M.C. (2016) Study on the Phytochemical, Antibacterial and Antioxidant Activities of Simarouba glauca. South Indian Journal of Biological Sciences, 2, 119-124. https://doi.org/10.22205/sijbs/2016/v2/i1/100358

[22] Hanato, T., Kagawa, H., Yasuhara, T. and Okuda, T. (1988) Two New Flavonoids and Other Constituents in Licorice Root: Their Relative Astringency and Radical Scavenging Effects. Chemical and Pharmaceutical Bulletin, 36, 2090-2097. https://doi.org/10.1248/cpb.36.2090

[23] Oyaizu, M. (1986) Studies on Product of Browning Reaction Prepared from Glucoseamine. Japanese Journal of Nutrition, 44, 307-315. https://doi.org/10.5264/eiyogakuzashi.44.307

[24] Madhuri, S. and Pandey, G. (2009) Some Anticancer Medicinal Plants of Foreign Origin. Current Science, 96, 779-783.

[25] Ara, I., Bukhari, N.A., Solaiman, D. and Bakir, M.A. (2012) Antimicrobial Effect of Local Medicinal Plant Extracts in the Kingdom of Saudi Arabia and Search for Their Metabolites by Gas Chromatography-Mass Spectrometric (GC-MS) Analysis. Journal of Medicinal Plants Research, 6, 5688-5694.

[26] Al-Daihan, S., Al-Faham, M., Al-shawi, N., Almayman, R., Brnawi, A., et al. (2012) Antibacterial Activity and Phytochemical Screening of Some Medicinal Plants Commonly Used in Saudi Arabia against Selected Pathogenic Microorganisms. Journal of King Saud University-Science, 25, 115-120.

[27] Marzouk, B., Marzouk, Z., Décor, R., Mhadhebi, L., et al. (2010) Antibacterial and Antifungal Activities of Several Populations of Tunisian Citrullus colocynthis Schrad. Immature Fruits and Seeds. Journal de Mycologie Médicale, 20, 179-184.

[28] Padalia, R.C., Verma, R.S., Chauhan, A., Goswami, P., et al. (2014) Compositional Variability and Antifungal Potentials of Ocimum basilicum, O. tenuiflorum, O. gra- 
tissimum and $O$. kilimandscharicum Essential Oils against Rhizoctonia solani and Choanephora cucurbitarum. Natural Product Communication, 9, 1507-1510.

[29] Balachandran, C., Duraipandiyan, V., Emi, N. and Ignacimuthu, S. (2015) Antimicrobial and Cytotoxic Properties of Streptomyces sp. (ERINLG-51) Isolated from Southern Western Ghats. South Indian Journal of Biological Sciences, 1, 7-14. https://doi.org/10.22205/sijbs/2015/v1/i1/100436

[30] Sreeshma, P.S., Raphael, K.R. and Baby, A.A. (2016) Pharmacognostic Studies of Leaves of Naravelia zeylanica (Linn) DC. South Indian Journal of Biological Sciences, 2, 179-182. https://doi.org/10.22205/sijbs/2016/v2/i1/100389

[31] Puthur, J.T. (2016) Antioxidants and Cellular Antioxidation Mechanism in Plants. South Indian Journal of Biological Sciences, 2, 14-17.

https://doi.org/10.22205/sijbs/2016/v2/i1/100335

[32] Nandhini, V.S. and Stella Bai, G.V. (2015) In Vitro Phytopharmacological Effect and Cardio Protective Activity of Rauvolfia tetraphylla L. South Indian Journal of Biological Sciences, 1, 97-102. https://doi.org/10.22205/sijbs/2015/v1/i2/100430

[33] Cota, B.B., Bertollo, C.M. and de Oliveira, D.M. (2013) Anti-Allergic Potential of Herbs and Herbal Natural Products-Activities and Patents. Recent Patents Endocr Metab Immune Drug Discovery, 7, 26-56. https://doi.org/10.2174/187221413804660935

[34] Takhi, D., Ouinten, M. and Yousfi, M. (2011) Study of Antimicrobial Activity of Secondary Metabolites Extracted from Spontaneous Plants from the Area of Laghouat, Algeria. Advanced Environmental Biology, 5, 469-476.

[35] Doss, A., Vijayasanthi, M., Anand, S.P., et al. (2011) Screening of Antimicrobial Activity of Essential Oil and Methanol Extracts of Citrullus colocynthis (L.) Schrad. South Asian Journal of Biological Science, 1, 7-15.

[36] Marzouk, B., Marzouk, Z., Mastouri, M., Fenina N. and Aouni, M. (2011) Comparative Evaluation of the Antimicrobial Activity of Citrullus colocynthis Immature Fruit and Seed Organic Extracts. African Journal of Biotechnology, 10, 2130-2134.

[37] Tsuchiya, H. and Iinuma, M. (2000) Reduction of Membrane Fluidity by Antibacterial Sophoraflavanone G Isolated from Sophora exigua. Phytomedicine, 7, 161165.

[38] Negi, P.S. (2012) Plant Extracts for the Control of Bacterial Growth: Efficacy, Stability and Safety Issues for Food Application. International Journal of Food Microbiology, 156, 7-17.

[39] Gill, A.O. and Holley, R.A. (2006) Disruption of Escherichia coli, Listeria monocytogenes and Lactobacillus sakei Cellular Membranes by Plant Oil Aromatics. International Journal of Food Microbiology, 108, 1-9.

[40] Gill, A.O. and Holley, R.A. (2006) Inhibition of Membrane Bound ATPases of Escherichia coli and Listeria monocytogenes by Plant Oil Aromatics. International Journal of Food Microbiology, 111, 170-174.

[41] Upadhyay, A., Upadhyaya, I., Kollanoor-Johny, A. and Venkitanarayanan, K. (2014) Combating Pathogenic Microorganisms Using Plant-Derived Antimicrobials: A Mini Review of the Mechanistic Basis. BioMed Research International, 2014, 18. https://doi.org/10.1155/2014/761741

[42] Halliwell, B. (2007) Biochemistry of Oxidative Stress. Biochemical Society Transaction, 35, 1147-1150. https://doi.org/10.1042/BST0351147

[43] Myburgh, K.H. (2014) Polyphenol Supplementation: Benefits for Exercise Performance or Oxidative Stress. Sports Medicine, 1, 57-70.

https://doi.org/10.1007/s40279-014-0151-4 
[44] Blokhina, O., Virolainen, E. and Fagerstedt, K.V. (2003) Antioxidants, Oxidative Damage and Oxygen Deprivation Stress: A Review. Annals of Botany, 9, 179-194. https://doi.org/10.1093/aob/mcf118

[45] Kasote, D.M., Katyare, S.S., Hegde, M.V. and Bae, H. (2015) Significance of Antioxidant Potential of Plants and Its Relevance to Therapeutic Applications. International Journal of Biological Sciences, 11, 982-991. https://doi.org/10.7150/ijbs.12096

[46] Yoshikawa, M., Murakami, T., Komatsu, H., Murakami, N., Yamahara, J. and Matsuda, H. (1997) Medicinal Foodstuffs: IV. Fenugreek Seeds. (1): Structures of Trigoneosides Ia, Ib, IIb, IIIa, and IIIb, New Furostanol Saponins from the Seeds of Indian Trigonella foenum graecum L. Chemical and Pharmacology Bulletin, 45, 8187. https://doi.org/10.1248/cpb.45.81

[47] Nirmala, P. and Ramanathan, M. (2011) Effect of Myricetin on 1,2 dimethylhydrazine Induced Rat Colon Carcinogenesis. Journal of Experimental Therapeutics and Oncology, 9, 101-108.

\section{Submit or recommend next manuscript to SCIRP and we will provide best} service for you:

Accepting pre-submission inquiries through Email, Facebook, LinkedIn, Twitter, etc. A wide selection of journals (inclusive of 9 subjects, more than 200 journals)

Providing 24-hour high-quality service

User-friendly online submission system

Fair and swift peer-review system

Efficient typesetting and proofreading procedure

Display of the result of downloads and visits, as well as the number of cited articles

Maximum dissemination of your research work

Submit your manuscript at: http://papersubmission.scirp.org/

Or contact pp@scirp.org 